\author{
DEPARTMENT OF THE INTERIOR \\ UNITED STATES GEOLOGICAL SURVEY
}

\title{
AEROMAGNETIC MAP OF PARTS OF THE MOTHER LODE GOLD AND SIERRA FOOTHILLS COPPER MINING DISTRICTS \\ CALIFORNIA, AND ITS GEOLOGIC INTERPRETATION
}

By

John R. Henderson, Jr., Arvid A. Stromquist, and

Anna Jespersen

\author{
GEOPHYSICAL INVESTIGATIONS \\ MAP GP-561
}

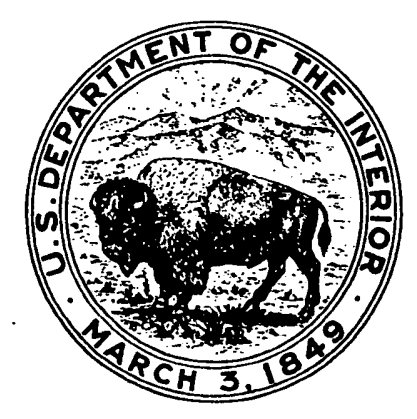




\title{
AEROMAGNETIC MAP OF PARTS OF THE MOTHER LODE GOLD AND SIERRA FOOTHILLS COPPER MINING DISTRICTS, CALIFORNIA, AND ITS GEOLOGIC INTERPRETATION
}

\author{
By John R. Henderson, Jr., Arvid A. Stromquist and Anna Jespersen
}

The geology of the western Sierra Nevada has been subject to investigation since the Gold Rush of 1849 50 , and many reports have been published. Rocks of the area were early divided into two groups, a steeply dipping, folded, faulted, and metamorphosed bedrock complex and the so-called superjacent series of unmetamorphosed, nearly flat lying alluvial and volcanic deposits. The bedrock complex consists of altered sedimentary and volcanic rocks of Paleozoic and Mesozoic ages and plutonic rocks of Mesozoic age; the superjacent series is of Tertiary age. Beds of the bedrock complex dip steeply or vertically and strike generally. northwestward. Ultramafic rocks, mostly altered to serpentine, occur as stocklike masses and as narrow elongated bodies in the major fault zones. The rocks are especially sheared within the fault zones; they are locally deformed west and east of the fault zones, probably because of the presence of shear zones more localized than the fault zones. Within and east of the Melones fault zone the volcanic-sedimentary rocks are of chlorite-biotite and, locally, garnet grades of metamorphism. Dominant rock types are phyllites, phyllonites, para- and ortho-gneisses, and mica schists including greenschists derived from intermediate to mafic volcanic rocks. The rocks west of the Melones fault zone are mostly of low chlorite grade of metamorphism. The area east of the Melones fault zone comprises in part the "western wall" of the great Sierra Nevada batholith. Here, diorite and granodiorite crop out over wide areas. In addition gold, copper, chromite, manganese and other mineral deposits have been mined in the map-area (Jenkins, 1948; Cater, 1948a and b; Taliaferro, 1943; Trask and others, 1950).

In the late 1940 's, the U.S. Geological Survey began a program of geologic mapping to study the regional structure and stratigraphy. An aeromagnetic survey of approximately 1350 square miles on the western slope was made in August 1951 in conjunction with this mapping program. Study of the magnetic patterns over this large area, in only part of which there had been detailed mapping, has aided in inferring the subsurface extent of intrusive bodies and their relation to ore bodies, in confirming mapped and concealed faults and other structures, and in determining whether the sediments at the east margin of the Great Valley of California were deposited against a fault scarp. These were some of the primary objectives of the survey.

The survey was made under the supervision of John R. Hendérson, Jr. John Bass supervised the compilation and prepared a preliminary aeromagnetic map, which was released to the open file in 1953. Arvid A. Stromquist and Anna Jespersen compiled the geologic map used in this report and contributed to the geologic interpretation of the aeromagnetic data.

The aeromagnetic map

Examination of the aeromagnetic map shows several distinctively different magnetic patterns. For con- venience, six zones are distinguished, three of high magnetic intensity, and three of low. Zone 1, along the western side of the area, is characterized by a northwesterly trending magnetic pattern with superimposed less pronounced westerly trends and moderately high intensity. Zone 2, across the middle of the area, is characterized by steep and intense elongated anomalies 1 to 5 miles long. Zone 3 is a broad zone of moderately high intensity $\mathrm{tr}$ ending southwestward across the eastern third of the map. Zone A, between Zones 1 and 2 , and Zones $\mathrm{B}$ and $\mathrm{C}$ in the north-central and southeastern parts of the map are characterized by negative closures with a few highs of low to moderate intensity.

Interpretation of the map

As rock type is reflected in the magnetic data, the geologic map compiled to aid analysis of the data shows lithology rather than stratigraphy. Seven lithologic types are distinguished: ultramafic rocks with which the highest magnetic intensity is associated; other intrusive rocks, with which the next lower order of magnetic intensity is associated; metasedimentary rocks; greenschist; metavolcanic rocks--all part of the bedrock complex; volcanic and sedimentary rocks of the superjacent series; and alluvial and marine deposits of the Great Valley.

A striking correlation between the trend of the regional structure and the magnetic grain is immediately apparent. The surface extent of intrusive bodies is outlined, especially the ultramafic rocks. The steeply dipping bedding is indicated by the pattern of strong magnetic highs with weaker lows to magnetic north, characteristic of steep-sided bodies magnetized by induction in the earth's magnetic field in middle latitudes (Vacquier and others, 1951, p. 117). The fault zones themselves are not indicated except where the mafic rocks have been intruded.

In the western part of Zone 1, for the most part there is no well-defined magnetic pattern, though there are several high-intensity anomalies over the alluvial and marine deposits of the Great Valley. The anomalies are similar to those associated with serpentine in Zone 2, and are believed to have a s imila r source. Pronounced northwest-trending anomalies in the southern half of the zone, the rather strong positive west-trending closure in the northern part of T. $2 \mathrm{~N}$., Rs. 9 and $10 \mathrm{E}$., and several small positive anomalies farther northeast may also be attributed to such sources. The intensity and trend of the anomalies suggest that serpentine occurs in shear zones at the western edge of the western block, as it does elsewhere in the Sierra Nevada.

In Zone 2, the strongest magnetic highs are associated with serpentine, magnetic highs of moderate intensity with the metavolcanic rocks, and magnetic lows with the greenschist. The greenschist has been 
mapped in the Melones fault zone and is clearly distinguished, magnetically, from the other metamorphic rocks with which it is in contact.

A striking example of correlation between magnetic pattern and rock unit is the delineation by the magnetic contours of the large serpentine body that extends northwestward from the south border of the area at about long $120^{\circ} 30^{\prime} \mathrm{W}$. to the northwest corner of $\mathrm{T}$. $1 \mathrm{~N} ., \mathrm{R} .13 \mathrm{E}$. (The reentrant in the magnetic contours in the center of the anomaly mayindicate a thinning of the serpentine body or a variation in magnetite content or degree of serpentinization.)

The strong positive magnetic anomaly west of Jamestown, in T. 1 N., R. 14, is caused by the serpentine exposed at the surface. The two bean-shaped highs northwest of this anomaly and the high near Angels Camp are all over metamorphic rocks, but the sources may be serpentine bodies at shallow depth in the shear zone. The northwest-trending high southwest of Quartz is primarily caused by the exposed mass of serpentine; extension of the anomaly across metamorphic rocks probably indicates that the serpentine body continues eastward at depth.

Strong but discontinuous anomalies are associated with isolated serpentine stringers west and northwest of Copperopolis. A medium-intensity magnetic high on the north boundary of the area at about long $120^{\circ} 45^{\prime} \mathrm{W}$. coincides with the Bear Mountains and correlates with mapped serpentine.

The magnetic pair, a positive high of intermediate intensity associated with a negative closure to the northeast, about halfway between Carson Hill and Columbia east of the Melones fault zone is over metasedimentary rocks and granodiorite, but the anomaly suggests serpentine is associated with the granodiorite at depth, perhaps emplaced along a shear zone.

Although the serpentine crops out discontinuously, the characteristic magnetic pattern associated with it crosses all of Zone 2 and suggests a more or less continuous body on which apexes are outlined by small, steep-gradient, closed magnetic highs.

Zone 3 is underlain chiefly by granodiorite of the Sierra Nevada batholith which has been intruded into metasedimentary rocks and which is overlain in places by Tertiary volcanic and sedimentary rocks. A major prong of the granodiorite is clearly outlined by the magnetic contours. In general there is a characteristic pattern of closed highs of moderate intensity over the granodiorite and the overlying rocks do not influence this pattern significantly. Three closed lows, one at the town of Standard, and the others about 2 miles northwest and 2 miles southwest of Standard, may indicate that the floor of the granodiorite body is locally shallow. The magnetic high at the eastern border may be caused by a facies change within the batholith.

Zone $\mathrm{A}$ is underlain by metasedimentary and metavolcanic rocks and is magnetically featureless. In Zone $B$, which is underlain chiefly by metasedimentary rocks and greenschist, the magnetic pattern is one of weak lows generally alined east-west. An isolated negative closure $2-1 / 2$ miles north of Angels Camp corresponds to an outcrop of ankerite talc schist (Clark and others, 1963). Small magnetic highs near Vallecito and Douglas Flat may be due to magnetiteand ilmenite-bearing sands that accumulated with the gold placers in the Tertiary stream beds. Rocks of Zone $\mathrm{C}$ are largely metasedimentary and have a westerly structural trend which is reflected in the magnetic pattern. The source of an isolated high near the southeast corner of the map is apparently in the granodiorite.
There is no indication in the magnetic data of a fault scarp at the east margin of the Great Valley.

\section{Analysis of anomalies}

Two magnetic anomalies, one in Zone 1 and the other in Zone 2, were selected for mathematical analysis. These are typical of anomalies in these zones and the amplitudes indicate rock masses of high magnetic susceptibility as the sources. Similarity of the two anomalies suggest similarity in lithology and structure of the sources.

Three comparisons were made. It was first assumed the bodies causing the anomalies were of approximately uniform magnetic susceptibility, of much greater extent along the strike than in depth below the surface, and of infinite downward extension. The depth of burial of the body crossed by section B-B' was estimated as 3000 feet by measuring the horizontal extent of the steepest part of the magnetic gradient. If the sources are similar, then an upward continuation (Henderson and Zietz, 1949) of the anomaly over the exposed serpentine body in $\mathrm{A}-\mathrm{A}^{\prime}$ computed to 4000 feet above the surface (the aeromagnetic data were taken 1000 feet above the surface) should resemble the anomaly in $B-B^{\prime}$. In fact, it does, as is shown in figure 1.



FIGURE 1-Observed and computed profiles of section $\boldsymbol{A}-\boldsymbol{A}^{\prime}$ shown in relation to observed profile of section $B-B$

A second comparison is provided by computing the magnetic profile over a body similar to that exposed in $A-A^{\prime}$ buried at a depth of 3000 feet. Calculations with a polar chart (Pirson, 1940, fig. 4) determined that an almost vertical-sided body about threequarters of a mile wide with a magnetic susceptibility of $0.016 \mathrm{cgs}$ would be suitable for computation. The susceptibility used is higher than has been observed for Sierra Nevada serpentines (DuBois, 1963) but the computed profile is in good agreement with that observed in $\mathrm{B}-\mathrm{B}^{\prime}$ (fig. 2). Finally, we computed a profile at 1000 feet above the surface, again with a polar chart, for the body exposed in section $A-A^{\prime}$ and the computed profile was found to be in good agreement with the observed profile (fig. 3 ). The lack of agreement at the nor theast end of the curves could be due to a small knob of mafic or ultramafic rock within the greenstone and reflected in the small anomaly southwest of Melones Reservoir. 


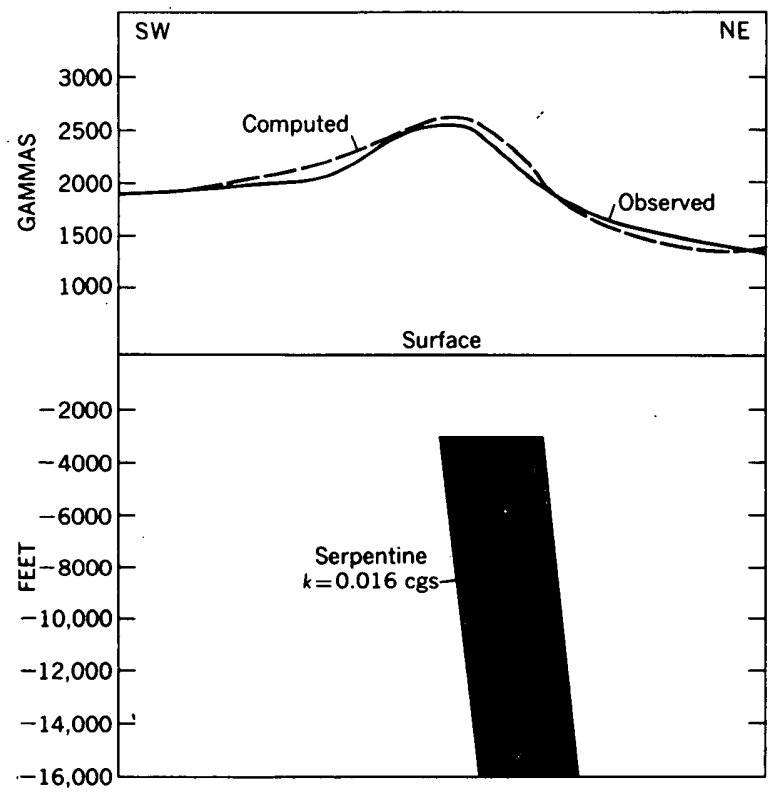

FIGURE 2-Observed profile of section $B-B^{\prime}$, compared with computed profile resulting from a body buried 3000 feet below the surface

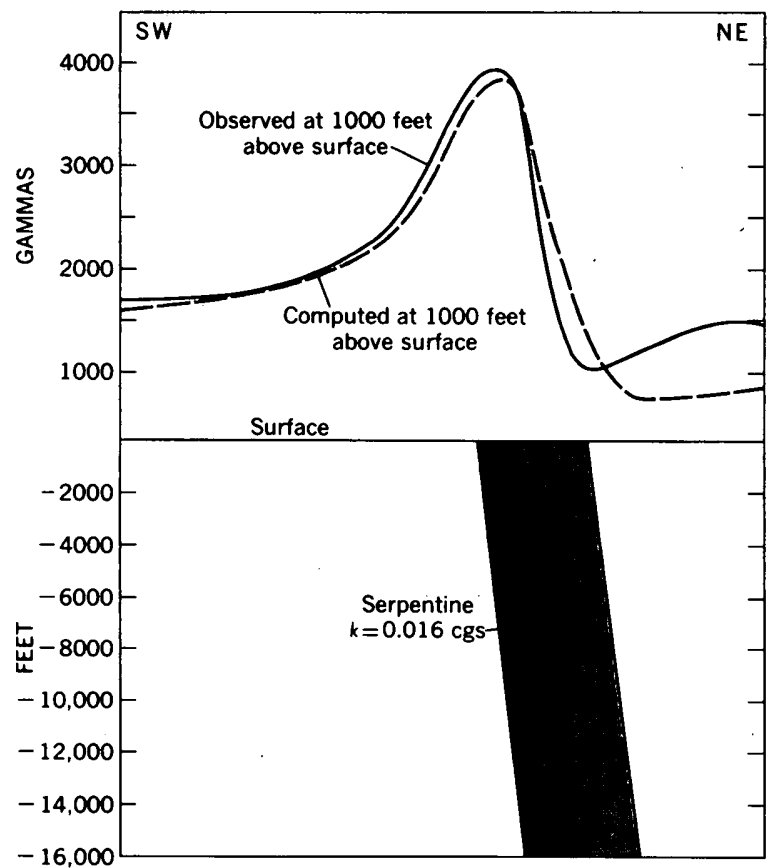

Figure 3-Profiles of section $A-A^{\prime}$, as observed and computed at 1000 feet above surface

Correlation of magnetic pattern and mineral deposits

In general there is no direct correlation between the magnetic pattern and known mineral deposits. However, many of the gold mines in the central part of the area are associated with shear zones and reverse faults. Copper-zinc deposits in the western part of the area are found along shear zones which have localized long, narrow belts of ultramafic and gabbroic rocks. Chromite mines and prospects are intimately associated with serpentine masses. It is possible that the similar structures, postulated along the CalaverasStanislaus County boundary, and ot her locales, from magnetic evidence, have similar gold, copper-zinc, and chromite deposits associated with them at depth.

Near Murphys, black sand associated with placer deposits has yielded 1416 pounds of magnetite and 200 pounds of ilmenite to the ton (Lindgren, 1911, p. 74). Such a concentration should be detectable by a magnetic survey (Joesting, 1941). Magnetically anomalous areas in the Tertiary deposits downstream from the contact with the main granitic body may be worth investigation for similar concentrations.

\section{References cited}

Cater, F. W., Jr., 1948a, Chromite deposits of Tuolumne and Mariposa Counties, California: California Dept. Nat. Res., Div. Mines Bull. 134, pt. 3 , chap. 1, p. 1-32.

1948b, Chromite deposits of Calaveras and Amador Counties, California: California Dept. Nat. Res., Div. Mines Bull. 134, pt. 3, chap. 2, p. 33-60.

Clark, L. D., 1960, Foothills fault system, western Sierra Nevada, California: Geol. Soc. America Bull. v. 71, p. 483-496.

Clark, L. D., Stromquist, A. A., and Tatlock, D. B. 1963, Geologic map of the San Andreas quadrangle, Calaveras County, California: U.S. Geol. Survey Geol. Quadrangle Map GQ-222.

DuBois, R. L., 1963, Remanent, induced, and total magnetism of a suite of serpentine specimens from the Sierra Nevada, California: Jour. Geophys. Research, v. 68, no. 1, p. 267-278.

Eric, J. H., Stromquist, A. A., and Swinney, C. M., 1955, Geology and mineral deposits of the Angels Camp and Sonora quadrangles, Calaveras and Tuolumne Counties, California: California Div. Mines Spec. Rept. 41, 55 p.

Henderson, R. G., and Zietz, Isidore, 1949, The upward continuation of anomalies in total magnetic intensity fields: Geophysics, v. 14, no. 4, p. $517-534$

Jenkins, O. P., 1932, Report accompanying geologic map of northern Sierra Nevada: Mining in California, v. 28, nos. 3, 4, p. 279-298.

1948, Copper in California: California Dept. Nat. Res., Div. Mines Bull. 144, 429 p. Prepared under the direction of Olaf P. Jenkins; contributing authors are H. R. Bramel, M. W. Cox, J. H. Eric, G. R. Heyl, A. L. Ransome, and D. G. Wyant.

Joesting, H. R., 1941, Ma g ne to m e t e $\mathrm{r}$ and directcurrent resistivity studies in Alaska: Am. Inst. Mining Metall. Eng. Tech. Pub. 1284, Class L, $20 \mathrm{p}$.

Lindgren, Waldemar, 1911, The Tertiary gravels of the Sierra Nevada of California: U. S. Geol. Survey Prof. Paper 73, $226 \mathrm{p}$.

Pirson, S. J., 1940, Polar charts for interpreting magnetic anomalies: Am. Inst. Mining Metall. Eng. Trans., v. 138, p. 173-185.

Smith, M. B., Lee, D. I., and Engler, V. L., 1959 , Basement wells in California and Nevada: U.S. Geol. Survey open-file rept., 130 p.

Taliaferro, N. L., 1943, Manganese deposits of the Sierra Nevada, their genesis and metamorphism: California Dept. Nat. Res., Div. Mines Bull. 125, p. 277-332.

Taliaferro, N. L., and Solari, A. J., 1946, Geologic map of the Copperopolis quadrangle, California: California Dept. Nat. Res., Div. Mines Bull. 145, pl. 1 .

Trask, P. D., and others, 1950, Geologic description of the manganese deposits of California: California Dept. Nat. Res., Div. Mines Bull. 152, (Supplement to Bull. 125), 378 p. 
Turner, H. W., 1894, Description of the Jackson sheet (Calif.): U. S. Geol. Survey Geol. Atlas, Folio $11,6 \mathrm{p}$.

Turner, H. W., and Ransome, F. L., 1897, Description of the Sonora quadrangle (Calif.): U. S. Geol. Survey Geol. Atlas, Folio 41, 5 p.
1898, Description of the Big Trees quadrangle (Calif.): U. S. Geol. Survey Geol. Atlas, Folio 51, 8 p.

Vacquier, Victor, Steenland, N. C., Henderson, R. G., and Zietz, Isidore, 1951, Interpretation of aeromagnetic maps: Geol. Soc. America Mem. 47, $151 \mathrm{p}$. 